\title{
UHF 波帯干渉計を用いた多重落雷および多地点落雷観測結果
}

$\begin{array}{llllll}\text { 正員 } & \text { 河 } & \text { 崎 } & \text { 善一郎 } & \text { (大阪大学) } \\ \text { 非会員 } & \text { 野 } & \text { 村 } & \text { 幸 } & \text { 司 } & \text { (大阪大学) } \\ \text { 学生員 } & \text { 吉 } & \text { 橋 } & \text { 幸 } & \text { 子 } & \text { (大阪大学) } \\ \text { 正員 } & \text { 松 } & \text { 浦 } & \text { 虔 } & \text { 士 } & \text { (大阪大学) }\end{array}$

Observation of Multiple Stroke and Multi-point discharge by means of UHF Interferometers

Zen Kawasaki, Member, Koji Nomura, Non-member, Sachiko Yoshihashi, Student Member, Kenji

Matsu-ura, Member (Osaka University)

Interferometric observations of cloud-to-ground flash in Darwin have been analyzed to investigate some features of the lightning. Our study focuses a comparison between multipoint and multiple negative cloudto-ground flashes. We estimate the speed of leaders with submillisecond resolution for both multipoint and multiple strokes. The leader that precedes first stroke for mutiple flash progresses in a stepped fashion, and its behavior seems to be similar to that for multipoint flash. The speed of the leader is estimated at the mean value to $10^{5} \mathrm{~m} / \mathrm{s}$ order, and the mean step length is found to be 96 meter with a mean pause time of 73 microsecond. The running time of the leader analyzed here takes the mean value of 89 microsecond. The duration of UHF radiation of leader which traces the former channel ranges from 0.2 to 55.3 millisecond with a mean of 7.5 millisecond. To the contrary, those preceding multipoint strokes ranges 21.1 to 90.6 millisecond with a mean value of 47.5 millisecond. The time interval between strokes which strike the same point as the former stroke ranges from 22.5 to 330.6 millisecond with a mean of 75.1 millisecond, and those for multipoint strokes ranges from 55.6 to 633.7 millisecond with a mean of 149.1 millisecond. All of the leaders preceding multipoint strokes starts at the same region inside the cloud.

キーワード : 熱带収束帯, 干涉計, 多重落雷, 多地点落雷

\section{1. はじめに}

大阪大学雷研究グループは, これまで雷放電進展機構 の解明を目的としてUHF 波帯干涉計による雷放電の可 視化を行い，それによる雷観測の有効性を検証してい る(1) ー(4)。その一環として, 熱帯収束帯における雷活動 の把握を目的とした雷観測を 1996 年 11 月 4 日〜 11 月 25 日及び 1997 年 11 月 22 日〜 12 月 13 日の合計約 2 ケ 間，オーストラリア北部のダーウィンにおいて行ってい る。Darwin 流 IKL (雷雨日数) が 80 以上であり，かつ高 層建造物も少なく電波障害が皆無に近い事から，雷観測 を行うには格好の場所である。のみならず，同地域では， 気象レーダ，到達時間差法を用いた落雷点標定 (ALDF), ロケット誘雷および雷雲雲頂と電離層間での放電現象で あるRed Spriteの観測も行われ，熱帯収束带における雷 活動の把握を目的とした総合観測が行われている。

同地区は，熱帯収束査であることから，負極性落雷の
割合が高いことがわかっている(5)。一般的に負極性落雷 は多重落雷の形態をとり, 電界変化記録等を用いてこれ まで数多くの報告がなされてきている(6)。さらに近年で は，干涉計などにより雲内の進展様相も含めその詳細な 事例解析が行われており, 負極性多重落雷の機構が次第 に解明されつつある(7)(8)。しかし，最近の報告 ${ }^{(9)(10) に ~}$ よれば,これまで多重落雷と考えられてきた負極性落雷 には約半数の多地点落雷が含まれていることが明らがと なってきており，これは帰還雷搫間隔など多重落雷の統 計量を見值す必要性を示唆している。また, 多地点落雷 に関する雷揧頻度や雷撃時間間隔などは耐雷設計などに 有用であると考えられ，いくつかの報告がある。例えば 清水ら ${ }^{(10)}$ は, 多地点落雷の電磁界の多地点観測を行い, その頻度について報告し, 送電線の事故解析への適用に ついて言及している。しかし, 多地点落雷に関して睍段 階では，雲内の放電活動も含めた詳細な放電路再現に基 づく解析は行われておらず，その生成要因や放電形態な 


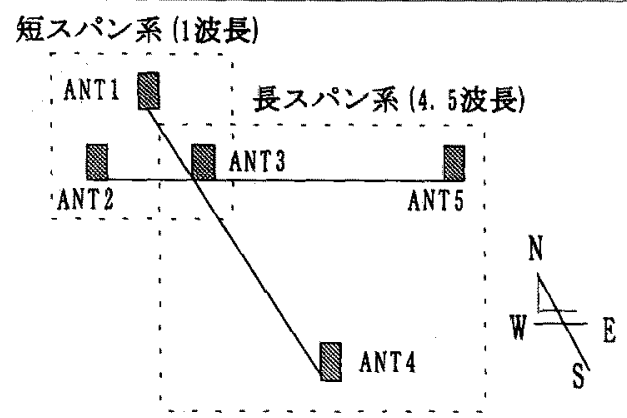

図 1 干渉計のアンテナ構成

Fig. 1. The antenna configuration of our interferometer

ど未解明な部分が多い。そこで，本論文ではまず，ビデ 才映像と干涉計による再現像を比較し，それらが一致す ることを示す。その上で，多地点落雷および多重落雷の リーダの特性に着目し，その進展速度および進展様相が， 多重落雷の第 1 州還雷䔩に先行するリーダと多地点落雷 のリーダで類似していること，言い換えれば，多地点落 雷のリーダと多重落雷の後続雷撃に先行するリーダでは 特性が異なることを，UHF千涉計による観測から示す。 続いて,リーダによるUHF電波放射継続時間，㷌還雷 撃間隔が，多地点落雷のリーダと多重落雷の後続雷撃に 先行するリーダでは異なることを統計的に示し，そのヒ ストグラムを報告する。

\section{2. 锶測システム}

本論文で用いる干涉計は，UHF 波带中の電波天文の保 護バンドである $327 \mathrm{MHz}$ を中心周波数とし，アンテナ配 列は図 1 に示す様に，直交する短長両スパンにより棈成 されている。さらに干涉計受信機の出力である位相差は， 各雷放電每にサンプリング周波数 $1 \mathrm{MHz}$ で 1 秒間記録し， 雷放電により放射される電波源位置の，锶測サイトに対 する仰角・方位角を，時間分解能 1 マイク口秒で求める ことが出来るよう設計されている。アンテナ配列として， 短長雨スパン系を用いる理由は，これらを組み合わせる ことにより，電波放射源位置としての明瞭な放電路像を 得るためであり，本論文で示す全ての放電路像は短長両 スパン系を用いて求めていることを強調しておく。

本観測では同時に 360 度全方位を撮影可能なビデオカ メラによる観測を実施している。ビデオデッキは市販さ れている Victor HR-X7 を用い，一秒間に 30 コマの撮影 が可能である。時刻管理はビデオタイマーを用い，10 ミリ秒の分解能を有している。時刻の校正は手動により 行っており，精度は約 1 秒前後と思われる。

\section{3. 解析結果}

図 2 に 1997 年 12 月 12 日 2 時 32 分 55 秒 (UTC) に 記録された雷放電の電界変化及びUHF 電波強度を示す。 全体として電界変化は負方向に振れており, 図中 Rと記し たいくつかの階段状の速い変化が記録されている。そし

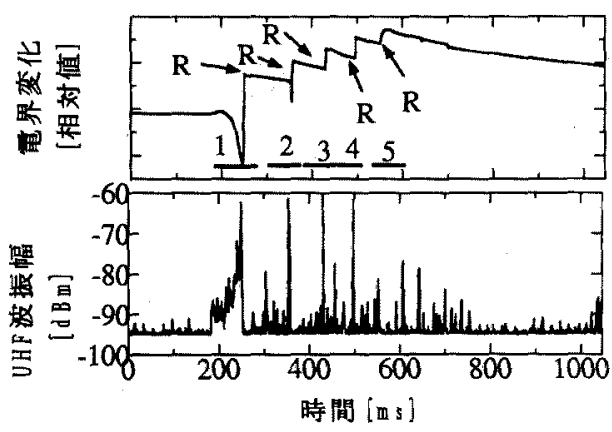

図 2 電界変化と UHF 波振幅全体波形

Fig. 2. Whole waveforms of electric field change and $\mathrm{UHF}$ radiation

てその変化前に対応して UHF 電磁波強度は大きくなっ ていることがわかる。この雷放電の最初の 3 雷撃の全方 位ビデオ映像を図 3 に，干涉計による電波放射源像を図 4 に示す。同図において，方位角は $0^{\circ}$ 北とし，反時 計回りを正としており，以下方位角の表記はこれに準ず る。図 3 のビデオ映像右下に時刻を記しているが，これは ダーウィン付近の地域時間であり，日本との時差は 30 分 である。同図の映像から放電路は地面に達しており，解 析対象としている雷放電が対地放電であることがわかる。 上述の電界変化およびU H F 電磁波強度の特徽はこれま でに報告されている対地放電の特徴と一致しており，電 界変化全体の正方向への振れからこの放電が負極性の落 雷であることがわかる。図 4 は放電路像の天球人の射影 であるが，前述の 3 雷揧の落雷地点は方位角 340 度から 345 度となっており，ビデオ映像と一致している。

ビデオ映像による放電路の発光と雷鳴との時間遅れか ら，雷慗点までの距離の推定が可能であり，従ってり一 ダの平均進展速度を求めることが出来る。図 2 に示した 多重落雷の場合, 時間遅れが 11 秒 18 であり, 観测地点 から落雷点までの距離は約 $3700[\mathrm{~m}]$ と推定できる。放電 路を大地に垂直な直線と仮定すると，仰角変化から放電 路像のリーダの平均進展速度を求めることが可能となる。 その結果を表 1 に示す。同表より，第 1 雷撃及び第 2 雷 撃は $10^{5}[\mathrm{~m} / \mathrm{s}]$ オーダであり，第 3 雷撃以降の後続雷撃は すべて $10^{6}[\mathrm{~m} / \mathrm{s}]$ オーダとなっていることがわかる。この リーダの進展速度は，放電の進展における休止期間も含 めたりーダの全体平均速度であるため，このままではス テッフ状の進展であることの確認が容易でない。そこで， 放電路像の 100 マイクロ秒間の移動平均值より，時間閂 数としてのり一ダ進展速度を求めることとする。移動平 均值を用いるのは，干涉計の放電路像が，分散を含んで いることを考虑しての上である。第 1 雷撃，第 2 雷整，第 4 雷慗に先行する 2 ミリ秒間の拡大図を図 5 に示す。同 図より，第 1 雷撃に先行するリーダは， $10^{6}[\mathrm{~m} / \mathrm{s}]$ オーダ の進展速度の極大值を持ち, リーダの進展と約 $50 \sim 100$ マイクロ秒の休止期間を繰り返しながら，間欠的な進展 


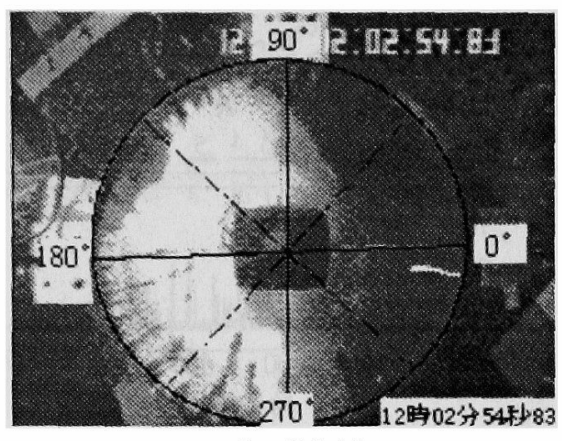

(a) 第 1 雷慗映像

(a) Video image of the first stroke

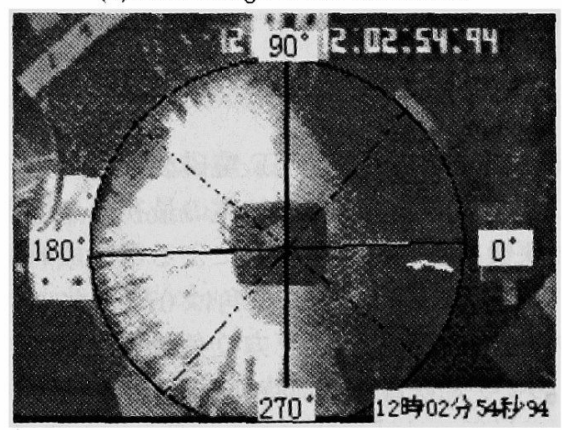

(b) 第 2 雷慗映湖

(b) Video image of the second strok

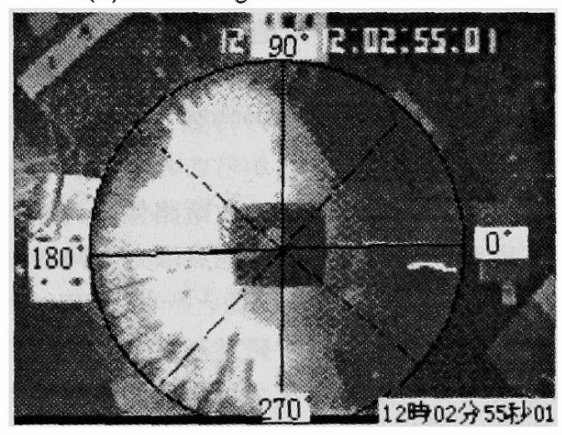

(c) 第 3 雷撃映像

(c)Video image of the third strok

図 3 多重落雷ビデオ映像

Fig. 3. Video images of the multiple stroke

をすることがわかる。リーダ先端の進展速度は $10^{6}[\mathrm{~m} / \mathrm{s}]$ オーダであるものの, 休止時間が含まれるため, 平均進 展速度は前のように一桁低い $10^{5}[\mathrm{~m} / \mathrm{s}]$ オーダとなる。第 2 雷撃に先行するリーダは, 極大值が $10^{7}[\mathrm{~m} / \mathrm{s}]$ 程度と高 速度を示し, リーダの進展期間と休止時間の間隔がそれ ぞれ長くなり, リーダの進展距離が第 1 雷撃のステップ ド・リーダより長くなっていることを示している。第四 雷撃に先行するリーダは, 極大值は $10^{7}[\mathrm{~m} / \mathrm{s}]$ オ一ダであ り,これは先行雷撃が 2 回起こり, 放電路が高い電離度 に保たれているためと思われる。

$\mathrm{UHF}$ 波干涉計を用いたこの種の考察は筆者等のグルー プでロケット誘雷では行われているが(4), 自然雷では全 く行われておらず，今回の結果は初めて電磁波観測を通

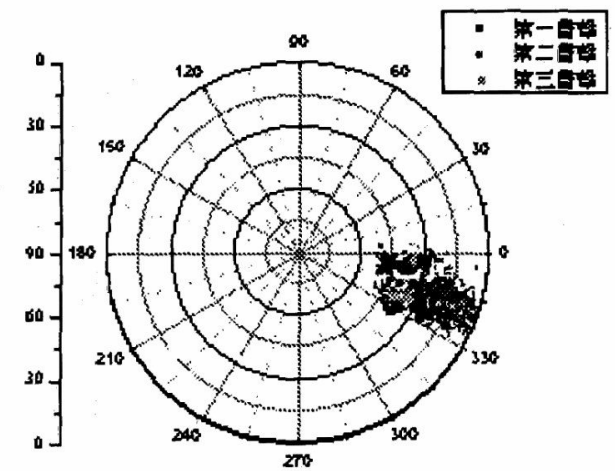

図 4 多重落雷干涉計放電路像

Fig. 4. Radiation sources of the multiple stroke

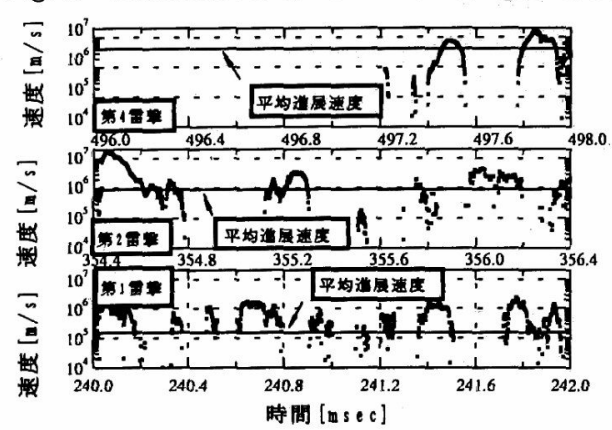

図 5 時間関数としてのリーダ進展速度 (多重落雷)

Fig. 5. The speed of the stepped leader versus time for multiple flash

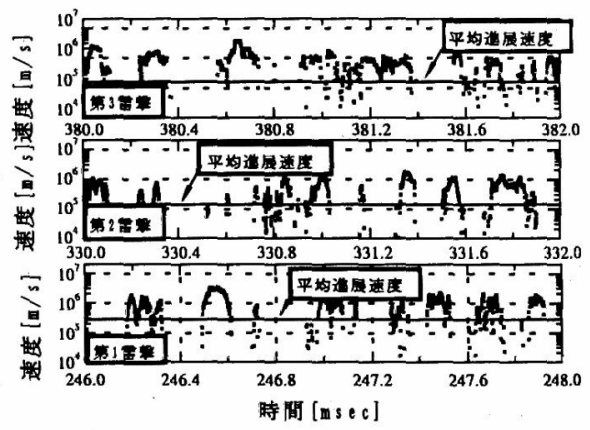

図 6 時間関数としてのリーダ進展速度 (多地点落雷)

Fig. 6. The speed of the stepped leader versus time for multipoint flash

じて高時間分解能でステップド・リーダおよび後続雷撃 に先行するリーダの進展速度及びその様相を解明したこ とを意味する。また, 多地点落雷に関しても帰還雷撃に 先行するリーダの進展速度を求めることができる。図 6 に 100 マイクロ秒の時間空でリーダの進展速度を算出し た結果を示す。また, 表 2 にその平均速度を参考までに 示す。この表より, 多地点落雷のリーダ速度は第 1 雷慗 に先行するリーダ速度に類似していることがわかる。こ れは，多地点落雷のリーダが，新たな放電路を形成する ため, その進展様相が, 多重落雷の第 1 㷌還雷揧に先行 するステップトリーダに類似しているためである。 
表 1 多重落雷のリーダ平均進展速度

Table 1. The average speed of each stroke in case of multiple flash

\begin{tabular}{|c|c|}
\hline 1 䈏革 & \\
\hline 第 2 雷 & \\
\hline 第3 雷 & \\
\hline 第 4 & \\
\hline 第 5 百 & on \\
\hline 第 6 雷 & $2 \times 10^{8}$ \\
\hline
\end{tabular}

表 2 多地点落雷リーダ平均進展速度（参考值）

Table 2. The average speed of each stroke in case of multi-point flash

\begin{tabular}{|c|c|}
\hline 第1雷重 & $2.9 \times 10^{5}[\mathrm{~m} / \mathrm{s}]$ \\
\hline 第 2 雷䝑 & $1.4 \times 10^{5}[\mathrm{~m} / \mathrm{s}]$ \\
\hline 第 3 霞撃 & $1.6 \times 10^{5}[\mathrm{~m} / \mathrm{s}]$ \\
\hline
\end{tabular}

統計的な考察を行うため，ビデオ映像と雷鳴の時間遅 れから瞬時速度を求められるステップトリーダ 4 例の進 展継続時間長，進展休止時間長及び進展距離のヒストグ ラムを図 7, 図 8 に示す。図 7 より，持続時間及び休止時 間ともピークが $20 \sim 40$ マイクロ秒と 100 〜 120 マイク 口秒に存在しており，バイモーダルとなっていることが 確認でき，平均值はそれぞれ89.0マイクロ秒，73.4マイ ク口秒となっている。図8よりステップの進展距離は 0 〜 $125[\mathrm{~m}]$ にしめる割合が約 $75 \%$ と高く, 平均值は 95.9[m] となっている。

\section{4. 統計からみた多重落雷と多地点落雷の相廷点}

本諭文で解析する事例はオーストラリア・ダーウィン で観测されたものであり，電界変化波形からすべて負極 性落雷と判断できる。多重落雷と多地点落雷との相違点 に関して考察を加えるため，それぞれ 10 例ずつ選択し， いくつかの変数に関して統計をとる。高木らの分類 ${ }^{(12)} に$ 従えば, 多地点落雷は, 放電路の途中で枝分かれした放 電路が大地に達する落雷（タイプB），先行する雷撃と後 続雷撃の雷撃地点が異なる落雷 (タイプC), 雲と大地 間に二本以上の放電路が見える落雷（タイプD）とに分 類される。これにより多地点落雷と多重落雷との区別は 干涉計により得られている放電路像に基づいて行い，タ イプCおよびDの多地点落雷を解析対象としている。

$\langle 4 \cdot 1\rangle \mathrm{UHF}$ 波带電波放射継続時間からの相造点 図 9に後続雷撃のリーダ開始に相当する UHF 放射の開 始から㷌還雷撃に至るまでのその電波放射継続時間の七 ストグラムを示す。同図において, 灰色のものが先行雷 慗と同地点に落雷するリーダを示し, 斜線のものが先行 雷撃とは異なった地点に落雷するリーダを表している。 データの総数はそれぞれ，48,12である。同地点に落雷 するリーダでは, UHF 電波放射継続時間が $0 \sim 5$ ミリ秒 の総数が全体の約 $71 \%$ を占め, 平均值は 7.5 ミリ秒（標 準偏差は 14.1 ミリ秒) である。最小值は 0.2 ミリ秒であ り，最大值は 55.3 ミ秒となっている。一方，異なった

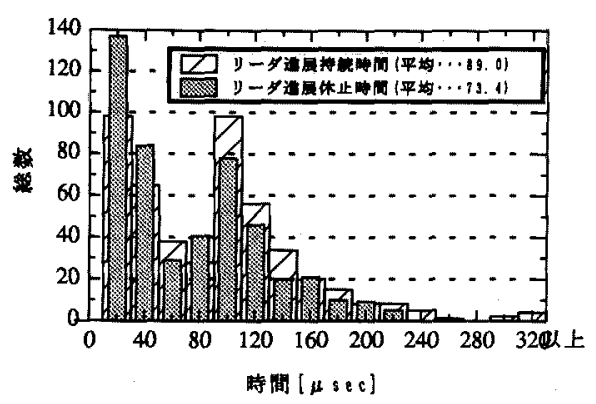

図 7 ステップトリーダの進展時間に関する ヒストグラム

Fig. 7. The histogram of the pause time and the running time of the stepped leader

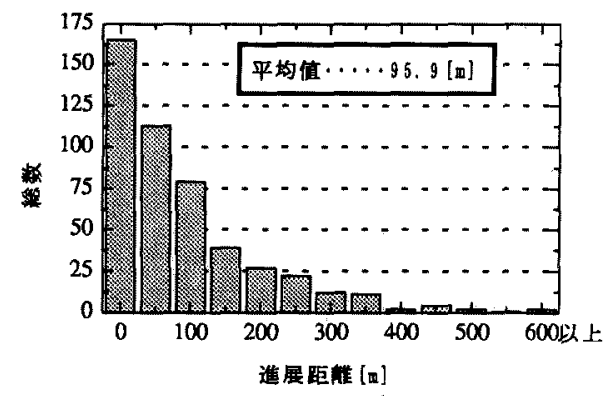

図 8 ステップトリーダの進展距離の ヒストグラム

Fig. 8. The histogram of the step length

地点に落雷するリーダでは，放射継続時間が最短のもの で 21 ミリ秒であり，最長のものでは 90 ミリ秒になる。 平均值は 47.6 ミリ秒で, 標準偏差が 22.6 ミリ秒となって いる。異なった地点に落雷するリーダの場合，同地点に 落雷するリーダと違い後続雷撃が先行雷煞とは異なる放 電路上を放電が進展するため，リーダは第 1 雷撃と同様 にステップド・リーダの形態をとることが多いためと推 測される。以上のことから, UHF 電波放射継続時間は, リーダが先行雷撃と同一放電路を進展するか否かの判断 パラメータとなり得るものと思われる。

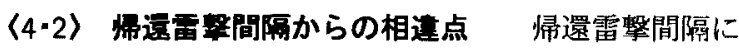
関寸るヒストグラムを図 10 に示し，その表記法は図 9 に 準じている。先行雷撃と同地点に落雷するリーダについ ては, 48 例, 先行雷撃と異なった地点に落雷するりーダ では 12 例について統計量を求めている。先行雷撃と同 地点に落雷するリーダでは，帰還雷撃間隔は最小值 22.5 ミリ秒から最大值 330.6 ミリ秒までの值をとり，平均 75 ミリ秒（標準偏差 57 ミ秒）である。一方，先行雷撃と 異なった地点に落雷するリーダでは，最小值 55.5 ミリ秒 から最大 633.7 ミリ秒までの值をとり，平均 149.0 ミリ 秒（標準偏差 158.7 ミ秒）である。連続電流の有無な どにより後続雷繋までの帰還雷撆間隔は左右されるもの の，同図より，異なった地点に落雷するリーダの方が全 体的に長くなっていることがわかる。殊に最短時間で比 較すると，同地点に落雷するリーダの場合は 22.5 ミリ秒， 


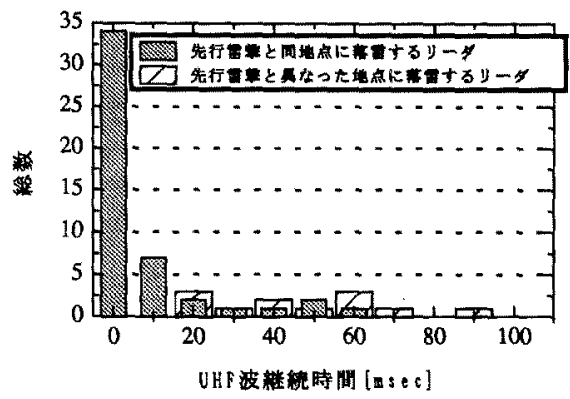

図 $9 \mathrm{UHF}$ 電波放射継続時間の ヒストグラム

Fig. 9. The histogram of the duration of the UHF radiation bursts for leader

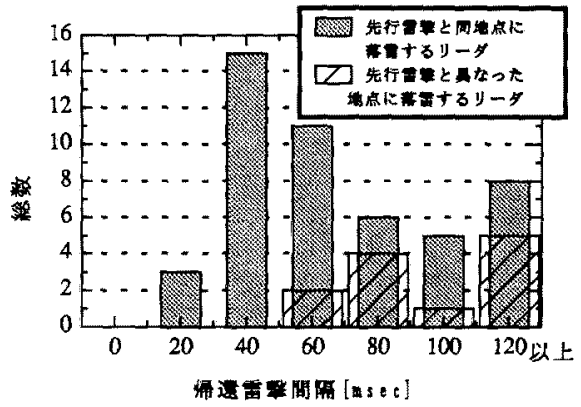

図 10 帰還雷撃間隔の

ヒストグラム

Fig. 10. The histogram of the time intervals between strokes

異なった地点に落雷するりーダの場合は55.6ミリ秒であ り，約 2 倍長くなっていることがわかる。また平均值に ついても約 2 倍の長さになっている。

〈4-3〉 雷繁の放電開始点からの相進点 次に, 放 電開始点に関して考察を加える。ビデオとの照合が行え ている多地点落雷の放電開始点を図 11 に示す。同図よ り，多地点落雷の放電開始点はすべて先行雷撃とほぼ同 位置にあることがわかる。多重落雷では，同一放電路を ダート・リーダが進展するため，同位圆から放電が開始す るが,一方，多地点落雷においても，多重落雷と同様に 同位置から放電が進展することが確認でき，この事から， 多重落雷と多地点落雷では放電開始点に関しては相違点 がないことが明らかとなった。また，他の事例 9例にお いても同様な結果が得られている。従って，今回の観測 結果に限って議論する場合，干涉計により，多地点落雷 でこれまでタイプDと判断されていた落雷は，雲内で共 通の放電路を持つタイプCであることが判断でき，多地 点落雷は多重落雷と同様, 一つの雷雲ないしはセルに蓄 えられている電荷によるものと結論できることになる。

\section{5. まとめ}

本論文では，オーストラリア・ダーウィンで行った雷 钼測で得られた負極性多重落雷及び多地点落雷に関する 統計から，それぞれの雷の相違点について考察を行った。 その結果以下の事が明らかとなった。

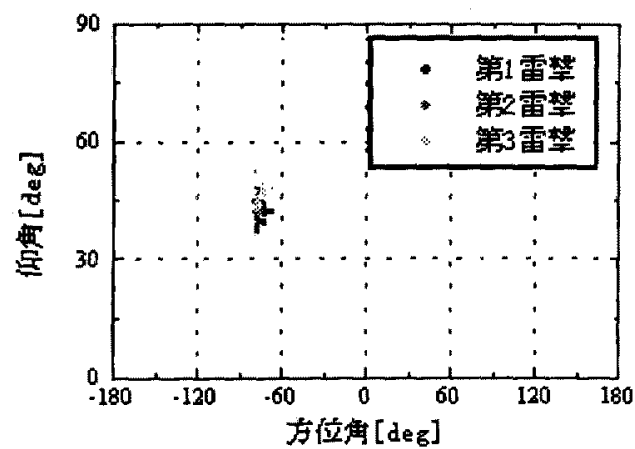

図 11 多地点落雷の各雷撃放電開始点

Fig. 11. The start point of the leader preceding return strokes for multipoint flash

（1）千涉計を用いて負極性多重落雷を解析した結果 電波源として求められる放電路像が，光学推測に よる放電路と一致し，干涉計の機能が確認された。

（2）負極性多重落雷のリーダの平均進展速度を，電 波源の進展速度という観点から算出した。

（3）従来の電磁界観測の解釈では，多重落雷に属す ると考えられる事象の中で，多地点への落雷が含 まれていることが確認された。

（4）UHF 電波放射継続時間が、後続雷䌘のリ一ダが 先行雷整と同一放電路を進展するか否かを判断す るパラメータとなり得ることを示した

（5）帰還雷揧間隔の最小值及び平均値は、異なった 地点に落雷するリーダの場合、同一点に落雷する リーダの約 2 倍長いことが明らかになった。

（6）今回の観測結果に限って議論する場合，先行雷 揧とは異なった地点に落雷するリーダと同地点に 落雷するリーダとの間に放電開始点に関しては大 きな違いはなかった。このことは, 多地点落雷も 同一電荷群から放電が開始していることを示唆し ている。

（7）ステップド・リーダの進展持続時關長、進展休 止時間長及び進展距離に関する統計を表した。進 展持続時間長及び進展休止時間長には二つのピー クが存在することなどが明らかとなった。

最後に本研究は, 文部省科学研究費 (国際学術研 究:10041142)の援助を受けており，本稿を終えるにあた りここに謝意を表する。また，本研究に際し，大貫潡氏 （現ソニ一），和田将一氏（現東芝）に多大なるご協力を 賜りました。御礼申し上げます。

(平成 10 年 8 月 28 日受付, 同 10 年 12 月 17 日再受 付)

\section{文献}

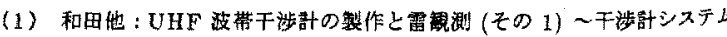
の性能群便〜，電学論，B-116(平 8-3)

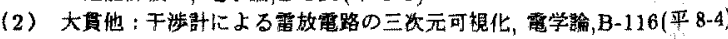


（3）大貫他：電波千涉計観則による上向き放電の特性, 電学論, B-1 17(平 9-4)

（4）和田他：UHF 波帯干涉計によるロケット䯕雷観测, 電学綸, B-117(平 9-4)

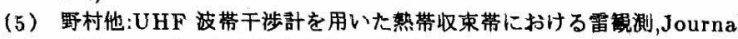
of Atmospheric Electricity., 17,1997

(6) Uman, M. A., The lightning discharge, Academic Press, 1987

(7) Shao, X. M., et al., Radio interferometric observations of cloud-to-ground lightning phenomena in Florida, J.Geophys.Res., 100, 1995

(-8) Rhodes, C. T., et. al, Observation of lightning phenomena using radio interferometry, J. Geophys. Res., 1994

(9) Rakov, V. A., et. al., Review of lightning properties from electric field and TV observation, J. Geophys. Res., 99, 1994

（10）清水他，多重落雷の電磁界による多地点同時䍉測，電学論，B-118, 1998

(11) Le Vine, D. M., and E. P. Krider, The temporal structure of $\mathrm{HF}$ and VHF radiation during Florida lightning return strokes, Geophys. Res. Lett., 4, 1977

（12）高木他，多地点落雷について，電学論,B-111,1991

河崎 善一郎 (正員) 1949 年 1 月 17 日生。1978 年 3 月大阪大

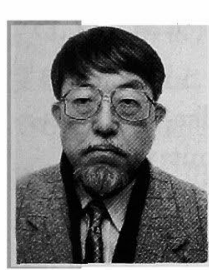
学大学院博士課程修了。1979 年 4 月 1989 年 7 月名古屋大学空電研究所勤務。1 1989 年 7 月大阪大 学工学部講師。1991 年同助教授、現在に至る。工 学博士。電磁界理論, 環境電磁工学, 雷観測, 絶 縁診断技術に関する研究に従事。1993 年日本大気 電気学会賞受賞, 1998 年電気学会進歩賞受賞。気 象学会, 日本大気電気学会, AGU, IEEE 各会員, 日本学術会議・電波研連委員。

野村 幸司（非会員） 1973 年 7 月 15 日生。1996 年 3 月大阪大

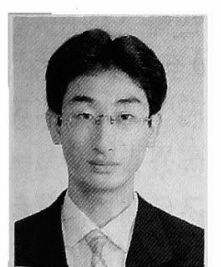
学工学部電気工学科卒業。1998 年 4 月大阪大学 大学院前期博士課程修了。同年 4 月トヨタ自動事 濑入社，現在に至る。

吉㮕 幸子 (学生員) 1973 年 8 月 30 日生。1998 年 3 月岐阜大 学大学院博士前期課程修了。同年 4 月大阪大学大 学院博士後期課程進学, 現在に至る。雷観测に関 する研究に従事。

伀浦 虔士 (正員) 1938 年 1 月 1 日生。1962 年 3 月大阪大学大

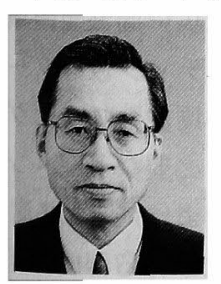
学院修士課程修了。同年 4 月住友電気工業 (株) 入 社。1977 年 1 月大阪大学工学部助教授。1988 年 3 月同教授。工学博士。電気エネルギーの発生・伝 送・変換・制御に関する研究に従事。1995 年 ITA アカデミアン。 